\title{
INTEGRATING THE CORPORATE INCOME TAX?
}

\author{
John K. McNulty*
}

Now that the late 1970s debate in the U.S. about the policy questions involved in "integrating" the corporate income tax with the individual shareholder income tax has quieted, and the activity in many nations to adopt some form of integration has slowed, it seems time for a good, reflective and technically masterful book on the subject. Such a book would be especially appealing if it took a comparative perspective and drew on the knowledge and experience of other highly developed economies and income tax systems. Appearing to be such a book is the volume by Martin Norr, The Taxation of Corporations and Shareholders."*

This valuable book, another in the series done in the International Tax Program of the Harvard Law School, has many virtues, of which-as with so many books-one or two are also its vices. Moreover, it needs one very important warning on its label. The warning should announce that this 1982 copyrighted book is really a 1977 book, and it consequently lacks a description of more recent developments in the law and analysis of the integration problem. Even though some recent literature (up to 1981) is cited in the footnotes and excellent bibliography, ${ }^{1}$ the text in effect stops in 1977 , for reasons of misfortune. The named author, Martin Norr, completed a draft of this study but had not revised it when he died in $1972 .{ }^{2}$ Others pitched in, especially Prof. Elizabeth Owens (Director of Research at the International Tax Program), who supervised a third year Harvard Law student, Christopher A. Klein, while he updated the manuscript to 1977, Professor Hugh Ault of Boston College Law School (whose Appendix, excerpted from his article, covers the 1977 German integration system), Prof. Richard M. Bird of Toronto, and far from least, Mr. Mitsuo Sato, of the Ministry of Finance in Japan. These collaborators have largely completed and updated the book to 1977 , and-spottily-later. ${ }^{3}$

Allowing for the fact that it does not cover some important recent developments in the U.S. and elsewhere, a few of which will be mentioned below, the reader will find this book to have many

* Professor of Law, University of California, Berkeley.

* The Netherlands: Kluwer, 1982. Pp. 197.

1. The bibliography has not comprehensively been brought up to date to the publication date, as some recent items lead the reader to think. [See, e.g., Auerbach \& Warren articles cited infra at $\mathrm{n}$. 24, which-though dated 1981-do not appear in Norr's bibliography or footnotes.]

2. See Norr, Foreword, by Prof. Oliver Oldman, Director of the International Tax Program at Harvard Law School, Norr, pp. XI-XII.

3. One troublesome failing consists of the absence of any index. 
strengths and much utility. ${ }^{4}$ Comparative fiscal law materials are scarce, ${ }^{5}$ and Martin Norr was an experienced hand at foreign, comparative and international fiscal law writing. ${ }^{6} \mathrm{He}$ and his posthumous collaborators were able to make comparisons about country systems and worldwide trends or tendencies. Such a book provides an easily accessible research source which can report facts or history that only an assiduous researcher with multi-language capabilities and enough knowledge and wisdom to make confident statements about the world as it is and has been could venture. The U.S. reader can learn much about the taxation of corporations and shareholders in other countries-more than most U.S. books and articles can provide. ${ }^{7}$ In addition, the book provides some observations and conclusions of its own, to which this review eventually will turn. As such, it is a highly organized, systematic, methodical, and quite thorough lawyer's job. It does not offer deep theory or a sophisticated economic/public finance approach. Its major deficiency is lack of coverage of U.S. (and some other) developments from 1977-1983, as this review will indicate. Consequently, it is not in some ways as useful as Charles McLure's superb 1979 book, Must Corporate Income Be Taxed Twice?, ${ }^{8}$ though it is richer in foreign experience and information. Now to the book itself.

\section{THE NORR BOOK}

Norr takes as his topic "the single most complex technical question in income taxation"-how to tax corporate source income to corporations and their shareholders-a problem sometimes referred to as the "double taxation" of corporate income, or the problem of "integrating" the two taxes. ${ }^{9}$

Norr sets out his monograph's organization like a "decision tree," with points of choice where limbs branch outward. He proceeds roughly as follows. If we have an individual tax, then what if (a) we also have a corporate tax or (b) we don't have a corporate

4. Originally intended to form part of the Tax Technique Series published by the International Tax Program at Harvard, the work "outgrew" that format and took shape as a monograph, which meant added length and a "research bibliography." See Forward, p. XI.

5. As one exception, see Soldati, "Taxing Corporate Income: European Harmonization and the Italian Experience," $24 \mathrm{Am}$. J. Comp. Law 246 (1976).

6. He wrote Taxation in France, published in 1966 by the Harvard Program and, among other things, a fine policy review, Norr, "Jurisdiction to Tax and International Income, 17 Tax L. Rev. 431 (1962).

7. See, however, Hammer, "The Taxation of Income from Corporate Shareholders: Review of Present Systems in Canada, France, Germany, Japan and the U.K." 28 Nat'l Tax J. 315 (Sept. 1975); Gourevitch, "Integration of Corporate and Shareholder Taxes in Income: The European Experience" (Lib. of Cong. Res. Serv. 1977) and 31 Tax Layer 65 (1977-1978); McLure, Must Corporate Income Be Taxed Twice?, (1979); "Imputation Systems-Objectives and Consequences," I.F.A. Seminar Paper, Montreal Congress (16 Sept. 1982).

8. McLure, supra n. 7.

9. Norr, Ch. I at 1. 
tax? If we have, and should have, both taxes, as Ch. II argues and concludes, should we integrate or remain un-integrated [Ch. III]? If integrated, at what level (corporate or shareholder) should the adjustment be made [Ch. IV]? If at one level (corporate), what form (split rate, deduction) [Ch V]? If at another level (shareholder), what form (exemption, credit) [Ch. VI]? Then, in Ch. VII, what about international aspects? Within each of these limbs of the tree are still other branches or forks to be chosen. His organization is excellent, clear and detailed. His methodology is thorough (sometimes almost too formal or classificatory).

To begin his analysis, Norr assumes an individual income tax already to be in place, and then raises and analyzes the pros and cons of whether a corporate tax should be added, which focuses the issue particularly in terms of how to tax corporate profits that are distributed to shareholders as individuals. ${ }^{10}$ He observes that most, but not all, countries have found a way to adjust the tax at either the corporate or shareholder level to take account of the tax at the other level. Yet no country seems entirely happy with the result and hence tinkering (or wholesale revision) everywhere makes the tax law unstable and repeatedly places further "reform" or fine-tuning on the agenda. (Political factors also contribute to the difficulties.) $\mathrm{He}$ declares that this study is designed primarily for the guidance of developing countries, but also for others. He calls attention to the differences between a publicly-held large corporation and a closelyheld private corporation to emphasize that there is no such single thing as "the corporation" for which a single system of taxation necessarily would be optimal. Instead, a variety of forms and combinations of corporate and non-corporate "entities" may require different tax regimes. This is surely a lesson of first importance for the student of "integration."

\section{Rejecting Complete Integration}

Having reached the point of two separate taxes in place, in $\mathrm{Ch}$. II Norr rejects wholesale or "complete" integration, which is to say complete relief from the extra burden of the corporate income tax on both distributed and undistributed corporate earnings. Although such relief, along the lines of a partnership tax model, may seem deserving as a goal, the book reports that in fact it is rarely if ever found and would not seem practicable to apply to the big, publiclyheld corporation. ${ }^{11}$

10. His arguments for the corporate income tax are even more necessary now, after it has been under still longer attack by integrationists, than it was when he wrote. He even draws on one of the most ingenious supports for a separate corporate-level tax: we need the corporate income tax for macro-economic control, including the ability to relieve that tax by allowances, incentives for capital formation and rate changes. Had Norr lived to see E.R.T.A. (The Economic Recovery Tax Act of 1981) in the U.S., he could have held it out as a prime example of such use of relief from the tax as a reason to enact or retain the tax.

11. The U.S. does have some experience with non-elective complete integration. 
Norr rejected this model, and its close relative, the Canadian (Carter) Royal Commission Report (1966), too hastily. ${ }^{12}$ Recent experience has encouraged the U.S. to relax its partnership-style taxation of electing "Small Business Corporations," not only to embrace more widely-held corporations (up to 35 shareholders), but also to make the Subchapter-S tax system move much farther toward, and nearly equal to, the partnership approach. ${ }^{13}$ Also, computers and associated technology, recording of data and inventive legal schemes very often make complete integration feasible now, even in the case of a large and publicly-held corporation.

Norr is not unwilling to consider impractical alternatives; he even discusses, as an heuristic device, the possibility of a rule making distribution of all corporate profits to shareholders compulsory, which would at least end those corporate tax problems arising from corporate retention of after-tax earnings. ${ }^{14}$ But this model is not to be taken very seriously. ${ }^{15}$

By Chapter III, following his rejection of complete integration, and after relating arguments for and against integration (with acknowledgement to Mitsuo Sato for "substantial revisions" incorporated) Norr really is discussing only "dividend relief," i.e., partial or complete integration for distributed profits only; he has placed partnership/transparency/Carter Commission "ideal models" behind him.

\section{Integration and Capital Gains Taxation}

Chapter III makes the key connection between integration and the taxation of capital gains. That is, if changing share values that result from retaining corporate profits are not included in shareholders' income (an "accrual approach") but are only taxed upon sale (a "realization" approach) or go untaxed because of an elevated, "fresh-start" basis at death (as under U.S. I.R.C. § 1014), the tax system has enacted "back-door" integration. This is true because there the individual income tax, at the shareholder level, has been removed (fresh-start basis), or deferred (until realization), which

A prominent instance is infamous Subpart-F (of the U.S. Internal Revenue Code) which taxes some U.S. owned controlled foreign corporations as if there were no separate entity, i.e., mandatory partnership-style "complete integration." While the U.S. shareholders affected may be huge, publicly-held corporations, the C.F.C.s are defined to include only closely held corporations, often subsidiaries.

12. Canada, Royal Commission on Taxation, Report of the Royal Commission on Taxation, 6 vols. (1966).

13. See the Subchapter-S Revision Act of 1982, now codified in I.R.C. $\$ \S 136-1379$, and enacted as Public Law 97-354, 19 Oct. 1982, effective for taxable years beginning after 31 Dec. 1982.

14. See Norr at 22.

15. Although the U.S. briefly tried to construct a system that would create strong tax pressure for distributions (1936-1938), and other countries have considered similar incentives, as in the Canadian Carter Commission report, (see, text, infra at n. 22), compulsory distributions are not the rule. 
often is nearly the financial equivalent of removal. ${ }^{16}$ In countries where "capital gains" on sale of shares are not taxed as income at all, the individual income tax has thereby been removed, or the two have been "integrated."

Another part of the key linkage between corporate tax integration and taxation of accrued but unrealized gains, briefly mentioned in Ch. II, is to see that if (contrary to most or all systems) shareholders were taxed currently on the annual accrued but unrealized gains (and losses) in their shares (market prices), the need for integration would disappear. This would be true because shareholders not only would be taxed each year on distributed corporate profits, as they are now under normal principles, but also on the market value of retained corporate profits, as reflected in their changed share values. ${ }^{17}$ This would amount to true Haig-Simons taxation of income. ${ }^{18}$

Accrual taxation of share values, however, would not be identical to transparency- or partnership-type taxation of retained corporate earnings because share values on the market do not always rise and fall in exact correspondence to retained earnings. Other factors (interest rates, evidence of future profitability of the firm or the industry, rumors, research and development announcements, dividend reductions or losses, etc.) may cause share prices to rise more than, or less than, the amount of retentions-or even to move in the opposite direction.

In choosing between partnership-style integration to tax retained corporate profits and Haig-Simons accrual taxation of sharevalue changes, many individual income tax theorists and reformers would choose the accrual approach as the best measure of the actual income of the shareholders. They presumably would also make this choice whether or not a separate corporate level tax of some kind or other were to be in effect. Under this view, failure to tax

16. The value of deferral of tax liability varies with prevailing interest and discount rates. Under $9 \%$ tax-free interest, for example, $\$ 100$ deposited at interest will grow to $\$ 200$ in 8 years, in effect removing the tax. At $18 \%$, $\$ 100$ will double in 4 years. Another way of viewing this is to say that the present value (cost) of paying $\$ 100$ in tax in 4 years under $18 \%$ conditions is (nearly) zero.

17. Accrual taxation of corporate share values has been seriously studied and recommended. See, e.g., Slawson, "Taxing As Ordinary Income The Appreciation of Publicly Held Stock," 76 Yale L.J. 623 (1967); Note, "Realizing Appreciation Without Sale: Accrual Taxation of Capital Gains on Marketable Securities," 34 Stan. L. Rev. 357 (1982); Thuronyi, "The Taxation of Corporate Income: A Proposal," 27 Tax Notes 179 (18 Oct. 1982).

18. The Haig-Simons "definition," drawing on that of Georg von Schanz and David Davidson, equates "income" to the algebraic sum of the market value of (1) actual consumption and (2) positive or negative change in net worth during the time period in question. See Kragen \& McNulty, Federal Income Taxation, Vol. I: Taxation of Individuals 154-66 (1979); Muten, Zur Entwicklung der Einkommensteuer nach dem ersten Weltkrieg 24 (1967).

On the implications of the Haig-Simons concept of income for integration analysis, see Gabinet \& Coffey, "The Implications of the Economic Concept of Income for Corporation-Shareholder Income Tax Systems," 27 Case W. Res. L. Rev. 895 (1977). 
shares values (and other values) on an accrual approach constitutes a flaw in the individual income tax itself. One who rejects this view may nevertheless support accrual taxation as an alternative to an unwanted corporate income tax.

If, however, such accrual taxation of share values were deemed impossible, for reasons of administration, compliance, valuation, or liquidity, then partnership-style integration would be a very good "second-best" tax policy. This line of thought, it must be said, treats the integration problem not as how corporations should be taxed but as one of "how shareholders should be taxed on corporate source income," and is given not so much as the gist of Norr's book but of the preference of others, including this reviewer.

So one sees that the solution to the integration problem may be influenced by whether one sets out to improve the individual income tax (in which event Haig-Simons accrual taxation seems the ideal and partnership-style complete integration a second best, with dividend relief a third choice) or to integrate the corporate tax and improve the relative taxation of distributed and retained earnings (in which event complete partnership integration or shareholder credit or dividend deduction solutions recommend themselves, in that order).

\section{Integration and Incidence}

Although the book does not make much of the corporate tax "shifting" or incidence problem, it does acknowledge it by referring to most systems in use today as compromises between complete integration and strict separation, between an assumption that the corporate income tax is shifted largely or entirely (to customers or employees) or not shifted (borne by shareholders, or dissipated over all holders of capital), as well as between an aggregate or an entity conception of "the corporation," and between large revenue losses and no loss. ${ }^{19}$ Others have made too much of the incidence problem which, at first or second glance, seems pivotal to the integration debate. This seems so because, if the corporate income tax is not borne by shareholders, if it is shifted forward to consumers or backward to employees, critics may ask "where is the second or double tax on shareholders which it is the avowed purpose of integration schemers to relieve?" The problem may seem to go away this easily, but it does not, and integration still makes sense in terms of economic efficiency and equity even if the tax is shifted. For a corporate income tax shifted to consumers becomes an erratic sales tax and if shifted to employees, an erratic payroll tax, in each case a tax whose burden varies positively with the profitability of

19. The Norr book generally is not economically sophisticated or inclined to supply much financial data (much less analyze it). Nevertheless, the authors of this Chapter III do quote Joseph Pechman in order formally and arithmetically to show an added burden of the corporate income tax (but without significant incidence analysis). 
the firm, and hence-presumably-with the firm's efficiency, an almost absurd tax policy.

Neither the sales tax nor the payroll tax makes policy sense, and both seem even less acceptable than a tax borne by shareholders or on all holders of investment capital. All holders of capital will experience a reduced after-tax rate of return in the corporate sector (reduced by the corporate tax), and in the noncorporate sector, by the extra flow of capital competing for a good return, and back again in the corporate sector as an equilibrium after corporate tax has been reached, with the entire economy suffering a dead-weight loss of efficiency and productivity. ${ }^{20}$ Relieving or removing the corporate income tax on any incidence assumption seems to make very good sense; maybe we don't have to solve the incidence puzzle to decide on integration policy.

Other economic/public finance issues do remain central to the integration debate but lie beyond the four corners this book. ${ }^{21}$

20. Announcement and imposition of a new corporate income tax might bear first on shareholders, as a sudden drop in the market values of their shares would manifest. Later investors might buy in at the new low prices, after the market has "capitalized" the new corporate tax. But this capitalization of the tax does not mean that new investors in corporate equities bear none of the tax, because the new equilibrium price of the shares may well make the yield a smaller percentage of the price paid for the shares than the percentages the original owners were enjoying. Similarly, as those former shareholders grope in the partnership or proprietorship sectors of the economy, they and others will drive prices up and rates of return will come down as a consequence.

21. The economic issues behind the integration debate are several in number and important in weight. They may be summarized as (i) the tax-created bias in favor of debt financing (vs. equity) and of financing by retained earnings and (ii) the dislocation of investment of capital resources between the corporate and non-corporate sectors. These biases have been studied as they influence the choice between debt and equity financing, the decision to distribute or retain corporate earnings, and as they may create a tax-induced discount in the market values of shares (and hence may depress investment in the corporate sector and overall investment). All these effects are interrelated, and also are connected to the capital gains preference and freshstart basis rules in the U.S. individual income tax.

Some leading studies on the debt-equity influence include: Modigliani and Miller, "The Cost of Capital, Corporation Finance and the Theory of Investment," 48 Am. Econ. Rev. 261 (1958) (tax creates strong bias in favor of debt financing); Tambini, "Financial Policy and the Corporation Income Tax," in Harberger \& Bailey, The Taxation of Income from Capital 185 (1969) (capital gains incentive to finance with retained earnings; rising debt-equity ratio increases the risk premium, and hence the cost of both equity and debt; some constraints exist against near $100 \%$ debt financing).

On the corporate income tax bias toward retaining corporate earnings (and the related issue of corporate investment policies) see: Litner, "Distribution of Incomes of Corporations Among Dividends, Retained Earnings and Taxes," $46 \mathrm{Am}$. Econ. Rev. 97 (1956) (market exerts forces for constant dividend flows; tax and other non-tax factors stimulate different dividend and retention policies); Feldstein and Frisch, "Corporate Tax Integration," $30 \mathrm{Nat} l \mathrm{Tax} J .39$ (1977) (dividend policies respond to changes in the tax structure); Feld, Tax Policy and Corporate Concentration (1982) (incentive to retain earnings does not contribute to corporate concentration, at least in any dominant way; other factors are very significant).

On the possibility of a tax-induced market discount of share values, see: Smith, "Corporate Taxation and Common Stock Financing," 6 Nat'l Tax J. 209 (1953) (lower 


\section{Integration and Revenue Considerations}

\section{Once again, Norr's discussion of this topic elbows aside partner-}

share valuation requires issuance of larger number of shares to raise targeted funds, which further dilutes earnings; other, non-tax market forces and other tax pressures (such as the capital-gains preference), can counteract, support, or overwhelm this tax-influenced phenomenon; market valuation reflects the cost of equity financing).

The macro-economic effects of the corporate income tax have been analyzed as being at least partly dependent upon the incidence of the corporate income tax, an unsettled issue that has moved from early demand-side theory to more refined theoretical work on the short-run shifting of the tax, the long-run static shifting and longrun dynamic shifting. Theoretical analysis having failed to yield a priori answers, the situation has called for empirical evidence which, when forthcoming, has not proven to be amply univocal or non-controversial. Thus the shifting issue seems still indeterminate. Nevertheless, some probably macro-economic effects have been identified and given some degree of weight.

The utility and effects of the separate corporate income tax in macro-economic ways have been studied to show the extent, if any, to which the corporate sector must bear a double (or extra) tax on its equity capital and to attempt to ascertain the macro-economic effects of this disproportionate tax burden. See, e.g., Goode, The Corporation Income Tax (1951) (supporting corporate tax on belief that the firm's capital bore the full burden of the tax at least in the short run and was paid mainly out of corporate or personal savings in the long run, with little or no reduction in consumer demand, which would contribute to strong corporate profits); Slitor, "The Corporate Income Tax," 5 Nat'l Tax J. 289 (1952) (supporting tax for revenue-raising, countercyclical influences, and fiscal utility).

Subsequent work began to indicate that market forces spread the tax cost throughout the economy so as to lower the equilibrium rate of return on all capital, and so as to distort prices from optimal levels. See Harberger, "The Incidence of the Corporation Income Tax, $70 \mathrm{~J}$. Pol. Econ. 215 (1962) (long run static effects of corporate income tax creating disequilibrium in capital markets, reallocation to non-corporate sector to equalize after-tax rates of return, dispersing the tax cost in the form of lower rates of return to all capital and inefficiently reallocating resources and thus generating deadweight welfare loss (excess burden) which reduces national income and national product; consumers do not bear entire cost of corporate tax; corporate tax also not completely shifted to labor, so long as labor can flow between corporate and non-corporate sectors; to extent that is not so, labor and capital would share the tax burden; under some conditions, capital may bear more than the full burden of the tax; Boskin, "Taxation, Savings, and the Rate of Interest," $86 \mathrm{~J}$. Pol. Econ. 86 (1978) (rate of savings responsive to interest rates; hence corporate income tax reduces rate of savings by lowering rates of return); Tideman \& Weber, Savings and Investment Aspects of Corporate and Personal Tax Integration: A Framework for Analysis (1975). Thus "dynamic theory" suggests that the corporate tax may reduce savings in several independent ways; restrained capital accumulation lowers wage levels and the tax becomes partly borne by labor.

Theory suggests that the corporate tax may be borne by capital, labor or consum$\mathrm{ers}$, in any combination. (One well-known study even seemed to show that the corporate income tax was shifted forward to consumers by more than $100 \%$. See Krzyzaniak and Musgrave, The Shifting of the Corporate Income Tax (1963).] Empirical studies have attempted to determine the actual effect. The results seem inconclusive, due to other variables and economic forces. See, e.g., Scanlon, "Post-war Trends in Corporate Rates of Return," in Public Policy and Capital Formation: A Study By The Federal Reserve System (1981); see generally Pechman, Federal Tax Policy, Ch. 5 ("The Corporation Income Tax,") 129-135 (1977); Klein, "The Incidence of the Corporate Income Tax: A Lawyer's View of the Problem of Economics," 1965 Wisc. L. Rev. 576.

Economic studies have also attempted to contribute to the analysis of the equity of the corporate income tax. Here, "equity" often is equated with "progressivity." Some analysts decry relieving a tax borne largely by higher income persons, while 
ship style integration as not used (and, perhaps, not feasible). Had he not done so, his presentation of the compromises offered (between integration and a "classical" system) would not have been the same. For example, full partnership-style integration probably would produce revenue gains compared to the classical, separatist systems, at least in settings when many individual shareholders are, or would be, taxed at rates higher than the corporation. (Such certainly was the case in the U.S. until 1981 E.R.T.A., before which individual income tax rates on investment income rose to $70 \%$, compared to a top corporate rate of $46 \%$.)

However, 1981 law lowered the top U.S. individual tax rate to $50 \%$, not much above the $46 \%$ top corporate rate; consequently the revenue gains from adopting partnership-style integration would be smaller or would become losses. In fact, most corporations pay U.S. corporate income tax at effective rates much below the top statutory, marginal rate of $46 \%$. This happens, especially after E.R.T.A. 1981 , not only from the fact that some of a corporation's income is

others see enhanced progressivity in removing a flat $46 \%$ tax (on corporate income) not geared to the ability to pay of the shareholder beneficiaries. Efforts have been made to measure the effective corporate tax rate on each marginal bracket, with the assumption that corporate equity bears the entire burden of the tax. See Pechman, Federal Tax Policy 136 (1977). That way, the corporate income tax seems quite progressive. If instead the incidence is assumed to be placed on all owners of capital and/or consumers, the results change markedly. If borne by all owners of capital, the tax may turn out to be fairly neutral, namely to constitute a constant proportion of income. In higher income brackets during pre-1981 higher maximum rate years, the tax shelter benefits of incorporation could outweigh the costs, especially when combined with deferral, preferential treatment of capital gains and fresh-start basis-a regressive result. See Pechman, id. at 93.

Moreover, the welfare loss of the tax should be taken into account under the criterion of "equity," as Harberger's, Shoven's and Feldstein's work suggests. See Harberger, "Efficiency Effects of Taxes on Income From Capital," in Krzyzaniak (ed.), Effects of Corporation Income Tax (1966); Shoven, "Efficiency Aspects of Taxes on Income From Capital," 84 J. Pol. Econ. 1261 (1976); Feldstein and Frisch, "Corporate Tax Integration," 30 Nat'l Tax $J$. 37 (1977). Of course, dividend relief will probably turn out to be less progressive than would "complete integration" in the partnership or transparency style. Similarly, dividend relief can be manipulated by corporate managers through payout policy, whereas complete integration does not leave a tax just on retained earnings, and it cannot be so easily manipulated by corporate distribution policies.

Either or both of these reforms (dividend relief and complete integration) must also be compared with a plain reduction in corporate tax rates, with or without a change in progressivity, as a means of reducing the distortions of the corporate tax. The last dollar of corporate tax paid may generate a much greater welfare loss than the first. So, a corporate tax rate change may act as a powerful subsidy or disincentive to the housing industry, which dominates the non-corporate sector of the U.S. economy.

The welfare gains from full integration substantially exceed those from dividend relief, perhaps by a factor of two. See Fullerton, King, Shoven \& Whalley, "General Equilibrium Approach to the Integration of the Corporate and Personal Income Tax," $71 \mathrm{Am}$. Econ. Rev. 677 (1981) (while keeping revenues constant by changes in the personal income tax system); their calculations showed gains that rival those earlier estimated by Harberger and Feldstein.

See generally, Ballentine, Equity, Efficiency, and the U.S. Corporation Income $\operatorname{Tax}(1980)$. 
taxed at rates lower on the graduated scale, but also partly as a result of tax preferences or allowances such as accelerated cost recovery (depreciation) and investment tax credits. Therefore, individual shareholders who have reached the $50 \%$ bracket (easier, owing to inflation) may be taxable at rates exceeding the actual corporate rate by ten, twenty or even thirty percentage points. Hence, taxing them at once on corporate earnings would enhance revenues. This effect would be undermined if similar preferences were "passed through" to shareholders or granted outright to individual investors.

\section{Integration and Recent U.S. Legislation}

The 1981 legislation in the U.S., nearly equalizing the nominal top individual and corporate rates, offers the U.S. a new and special opportunity, which, of course, Norr could not anticipate and for which he failed to lay a foundation by pretermitting analysis of the Canadian Carter Commission proposal. After 1981, the U.S. finds itself to be in a better position to put into effect the complete integration system recommended by the Canadian "Carter Commission" report, a system that requires an exact or close correspondence of top corporate and shareholder rates. ${ }^{22}$ This system ingeniously would "allow" a corporation that did not distribute any or all its after-tax earnings, to "allocate" retained earnings to shareholders while actually retaining them. The retention could serve the corporation's (or corporate manager's) need for liquid funds, while the "allocation" would be treated as a constructive distribution to shareholders, making them taxable as if they had received an actual distribution (grossed-up by the corporate tax paid) and providing them a shareholder credit for the corporate tax paid on their behalf and as an advance collection of shareholder tax later to be credited.

A key part of this proposal lay in the fact that all shareholders taxed up to $49 \%$ (if $50 \%$ were the maximum individual and the top corporate rate as well) would be expected to call and vote for "allocations" because every $\$ 1$ of allocation taxable to them (at $0 \%$ to $49 \%$ ) would bring out a $50 \%$ credit-meaning a refund since their own rates $(0-49 \%)$ would be lower. Even the $50 \%$ bracket shareholders at most would be indifferent, since their $\$ 0.50$ tax would fully be offset by the $\$ 0.50$ shareholder credit. The relationship between the top rates of the two U.S. taxes in recent decades has consisted of a 24-41 percentage point spread; only after the 1981 legislation have the two moved close together, and the U.S. should reconsider integration again, along Carter Commission lines while this opportunity remains. ${ }^{23}$

However, the fact that the U.S. has virtually "repealed" its cor-

22. Canada, Royal Commission on Taxation, Report of the Royal Commission on Taxation (6 vols.) (1966, 1967).

23. See Break, "Integrating Corporate and Personal Income Taxes: The Carter Commission Proposals," 34 L. \& Contemp. Prob. 726 (1969); Break, "Integration of the Corporate and Personal Income Taxes," 22 Nat'l Tax J. 39 (1969). 
porate income tax by such generous investment tax credits and accelerated cost recovery allowances as to enable some firms and some industries to bring their effective tax rates to a very low amount, or even to enjoy a "negative income tax,"24 either steals much of the impelling force from the integration movement or at least vastly accentuates the problem of "over-integrating" by giving to a shareholder an integration (imputation) credit for more than the amounts of the tax actually paid "for him/her" by the corporation. ${ }^{25}$ These latter considerations, though pre-1982, are ones this book does not even report, much less take into its discussion perhaps partly because, as mentioned earlier, it essentially stops with $1977 .{ }^{26}$

\section{Integration Mechanisms: Shareholder or Corporate Level}

So, the book advances to the point of asking whether, if some form of adjustment of the two taxes is to be made, ${ }^{27}$ it should take place at the corporate level ${ }^{28}$ or at the shareholder level. ${ }^{29}$ Still assuming that relief will be given only for distributed profits, as a result of the $\mathrm{Ch}$. III conclusions and what most integration countries in fact do, Norr consequently assumes a revenue loss (of some dimension) if any integration ("partial integration" or in McLure's helpful terminology, partial or complete "dividend relief") is adopted, a revenue loss corresponding to the relief from double taxation, or over-taxation, that is given by the integration mechanism. So here too his line of thinking by-passes any extensive discussion of complete integration under a partnership (or Carter Commission) style tax structure, an analysis that would have revealed the possibility of revenue gains from taxation of all corporate income once, and at the rates applicable to individual shareholders, many of whom are taxed at the margin at higher rates than the applicable corporate rate.

In discussing various forms of corporate level dividend relief, the author skillfully exposes the fact that formally different allowances can become mathematically or financially equivalent; a deduction for dividends can be set to equal any given rate of grossedup credit, for example. He enriches the discussion by some refer-

24. See Warren, "The Relationship Between the Corporate And Individual Federal Income Taxes After the Economic Recovery Tax Act of 1981" in N.T.A./T.I.A. Proceedings of the 74th Annual Conference at 28 (1981). 1981 E.R.T.A. made the present value of ACRS deductions and ITC credits roughly equal to the present value of expensing the entire cost of recovery property in the year of purchase. In the same volume, at p. 21, see Auerbach, "Tax Integration And the 'New View' of the Corporate Tax: A 1980's Perspective."

25. Even before E.R.T.A. 1981, the U.S. integration movement in scholarly and legislative circles had foundered on this problem of tax preferences and effective tax rates. See McLure, supra n. 8 at 92-145, 227-234.

26. See text, supra at $n .2$.

27. Norr at Ch. IV.

28. Norr at Ch. V.

29. Norr at Ch. VI. 
ences to experiences in other countries. He finds that shareholderlevel systems have become the choice of several important countries, such as France and the U.K., or have been combined with corporate level relief in some noteworthy "mixed" systems, such as in Germany since 1977 and in Japan for many years. Since most of the U.S. literature and legislative presentations on integration show no knowledge of the Japanese systems and experience, or at most give it only a cursory description, the more extended treatment and more frequent incorporation in this book shows a better range of research and a broader "world view," possibly owing in part to Mitsuo Sato's influence.

Having established that a shareholder-level adjustment must be considered, Norr moves on to evaluate the various mechanisms in this category, namely shareholder imputation credits and an exclusion for dividends.

\section{The Shareholder Imputation Credit}

The shareholder imputation credit has become the integration mechanism of choice (e.g., in France, the U.K. and Germany) particularly because it allows the tax system to deny the integration relief to foreign shareholders (and also to tax-exempt shareholders or other special shareholder categories). Hence, the book saves much of its extended analysis of the credit system for Chapter VII on "International Aspects."

When the imputation credit mechanism is described and analyzed at the earlier point, Norr selects as one main issue the question whether to make the shareholder "gross-up" his dividend actually received by the amount of corporate tax paid (or presumed to have been paid) on the corporate earnings from which the corporate tax and the actual distribution to the shareholder were made. He rightly concludes that the gross-up should be required in order to make the system fair and progressive (in proportion to underlying individual income tax rates). Without a gross-up, the credit is worth more, in a way, to a high-bracket shareholder than to a lowbracket shareholder. It then amounts to a tax-exempt payment by the corporation of the shareholder's tax liability, and an exemption or exempt payment is income-variant, worth more to a high-bracket than to a low-bracket taxpayer (so long as tax rates are graduated upward with income). ${ }^{30}$

30. Norr also rightly concludes that, to be income-constant, the credit must be not only taxable (the gross-up) but refundable as well, even though the refund process is expensive and complex to administer. As a consequence of the refundability feature of the credit, even a taxpayer who owes no tax before the shareholder credit is taken into account will not be denied the credit to which he is entitled because some tax was "withheld" on his behalf by the corporation. The credit is given to reduce the corporate income tax burdens, not merely the shareholder's individual income tax.

To be sure, as Norr acknowledges (at 130ff.), supporters of a shareholder credit without gross-up argue that such a credit is equitable in that it offers all shareholders the same unit amount of relief and because an equal unit of relief grants greater 
(Notice how all this discussion of the shareholder credit mechanism implicitly treats the corporation's income as if it were the income, pro-rata, of the shareholders, and treats the corporate level tax as if it were an advance payment of the shareholder's ultimate individual income tax. The Norr book does this, as do many other writers. The potential for trouble would lie mainly in failing to recognize what one is presupposing-for example, in deciding whether to require a gross-up of dividends, or to presuppose it while still discussing whether the corporation's income is its own or merely an aggregation of the shareholders' incomes.

\section{Parallels between the Imputation Credit and the (Indirect) Foreign Tax Credit}

In the course of this analysis of the shareholder imputation credit method of integration, Norr makes a comparison that is rare in the literature. He explicitly likens the shareholder imputation credit to the foreign $\operatorname{tax}$ credit given by the U.S. and other countries (the "indirect" or "deemed-paid" credit of I.R.C. \$902) for foreign taxes paid by a corporation (or other separate entity) owned by the domestic taxpayer (itself a corporation in the case of the U.S. $\S 902$ foreign tax credit). The importance of this comparison (undeveloped in this book) lies in the ideas, experience, parallels and comfort that one may draw from the system of foreign tax credit rules when designing or evaluating a set of imputation credit rules. To my knowledge, no one has as yet worked out how an imputation credit would look if modelled on the U.S. $\$ 902$ credit, with its underlying rules about "accumulated profits" and other bells and whistles, at least some of which get at the problem of underlying tax preferences or rates, and the ordering or tracing of distributions to income that was taxed at such and such rate, the problem that stalled the integration movement in the U.S. in the late $1970 \mathrm{~s}^{31}$

\section{Shareholders Credit Rate and Corporate Tax "Preferences"}

In turn, Norr's discussion does lead him to the solutions that other countries, from whom the U.S. has so much to learn, have devised to make sure that a shareholder is not given credit for more tax than the corporation itself has paid with respect to the earnings out of which it distributed a dividend. ${ }^{32}$ France, as an alternative to

proportionate relief to lower-bracket shareholders (except those who are not taxed, even without the credit, if the credit is not refundable). This notion of fairness seems inferior to the argument for a taxable gross-up on the ground that a credit without taxable gross-up (such as Japan and Canada have used) would remove an increasing proportion of the additional burden of the corporate income tax as the shareholder's income rises. See Norr's table at 131.

31. See McLure, supra n. 7 at Ch. 4.

32. This problem of how to handle tax preferences and low-taxed income (along with handling tax-exempt and foreign shareholders) helped halt the integration debate in the U.S. See McLure, supra $n$. 7 at Chs. 4-6, and 211, 227-235, 247-250.

It also spawned complex limitations called by Rep. Ullman a Shareholder Credit 
"tracing rules" that could be used in tandem with a variable credit (one corresponding to the actual rate of tax paid by the corporation), has chosen a uniform credit and an extra, compensatory tax called the precompte mobiliere. With a uniform credit (the "avoirfiscal"), which is far more desirable than a variable one, the French system insures that the corporation has paid enough tax to warrant the credit level, to compensate for the difference between credit level and actual tax rate of the corporate income tax. The précompte itself is creditable. This entails complexity, compliance and administrative costs, more so in the international arena, but seems'nevertheless a good solution and a bearable one. ${ }^{33}$ Quite possibly it is better than fixed presumptions or tracing rules or ordering presumptions. But, it should not be evaluated except in direct comparison with the major policy alternative in the late 1970s U.S. proposals, by the House Ways and Means Committee Chairman Lloyd Ullman and by the U.S. Treasury Department for a "Shareholder Credit Account" (or R.I.T.A.) to provide a device to limit the integration credit by some percentage of corporate income tax actually paid by each corporation. Unfortunately the Norr book, unlike that of McLure, does not go into the S.C.A. and similar proposals, much less make a comparative appraisal.

So at the brink of international consideration, the Norr book seems to suggest, or to generalize from actual policy choices of countries with "advanced" fiscal systems, and in speaking at least partly to developing countries, that partial or wholesale dividend relief by a shareholder level, imputation credit system will prevail as sound policy, perhaps partly for international as well as purely domestic consideration, although not without many countervailing considerations, "ifs, ands or buts." But the "International Aspects" chapter (VII) next deals almost a crushing blow to this line of thinking.

\section{International Aspects}

In Chapter VII, this book describes the various national systems at work, their pros and cons, and other proposals or experience in a most superior way. Before it ends, this chapter (intentionally) leads the reader toward a conclusion that integration may not be worth all its consequences and that the classical, unintegrated system (such as the U.S., almost alone among the large developed countries), may be best in the long run.

This is a view Sato has expressed elsewhere, ${ }^{34}$ one reported to

Account (S.C.A.) or (by McLure and others) a Refundable Income Tax Account (R.I.T.A.) which would maintain a record of actual corporate tax liability for each firm, or a percentage of corporate tax, as a limit on the total amount shareholders could take as credits. See McLure, supra n. 7 at $144-45$.

For recent data on rates of tax paid by corporations in the U.S., see Jt. Comm. on Tax and G.A.O. Study, Cong. Rec., 20 Dec. 1982 at H10545-105049.

33. See Norr at 139; McLure, supra n. 7 at 52, 73, 77 and 213-14.

34. For example, see Sato, "International Aspects of Integration of the Corporate 
the E.E.C. by van den Temple as long ago as 1970 and by others, ${ }^{35}$ often resting the case on international considerations, where unintegrated systems can be fitted together much more easily. This fitting process has to do with each country's mechanism for alleviating international double taxation.

\section{INTERNATIONAL DIMENSIONS}

The complexity that integration adds to any country's national tax system becomes multiplied when international considerations are introduced. For example, should corporate level (Ch. 5) or shareholder level (Ch. 6) relief be extended to non-resident corporations? Or to resident shareholders in foreign corporations? To nonresident shareholders in domestic corporations? Norr reports that, as an empirical matter, the answers to these questions tend to flow from the level at which domestic integration relief is granted. ${ }^{36}$ Systems that allow integration at the corporate level tend to offer that same relief on a qualifying distribution whether going to a resident or a non-resident shareholder. In contrast, shareholder level systems tend to restrict relief to resident shareholders and to exclude non-residents from their benefits.

Lest this sound as though the international rules follow automatically from the choice of level, the reader must be mindful that these international outcomes have often determined the choice of level. A country that wishes to grant integration relief to resident shareholders of its corporations because of its own "double taxation," but which wants to deny such benefits to non-resident shareholders of its own corporations, will find that a corporate level deduction for dividends or split rate for distributed profits cannot conveniently differentiate between domestic and foreign shareholders. The corporate advantages naturally will inure to the benefit of all shareholders. By adopting shareholder level relief, such as a grossed-up credit, the integrating country can disallow the credit to all but its own domestic shareholders. Hence France and other E.E.C. countries became persuaded that shareholder level relief was preferable to corporate level relief. ${ }^{37}$ Similarly, if integration is installed at the corporate level in Country A, it will not provide any

and Personal Income Taxes," 8 Ga. J. Int. \& Comp. L. 779 (1978); Sato and Bird, International Aspects of the Taxation of Corporations and Shareholders, 22 I.M.F. Staff Papers 384 (1975); Byrne \& Sato, "The Domestic Consequences of Alternative Systems of Corporate Taxation," 4 Pub. F.Q. 259 (1976).

35. See Cardyn, "General Report: The Multiple Burden on Dividends and Shares by Taxation on Income and Capital of Both Corporations and Shareholders," $55 \mathrm{a} \mathrm{Ca}$ hiers de droit fiscal International, I/39, I/67 (1970); I.B.F.D. Annual Report 5-6 (1964); "Structure de l'impot des sociéties," (Doc. 7228) XIV/70-D de la Commission des Communautés Européenes du Mai 1970, If 8, reprinted in 41 La Fiscalité du Marché Commun 93, 97 (1970).

36. See Norr at 152.

37. See Gordon, "International Fiscal Arrangements Distorted by Foreign Tax Policies; New Rules Needed," 37 J. Tax. 113 (1972); and see the "Segre Report," Communauté Economique Européene, Commission, Le Développement d'un marché 
benefit to shareholders resident in $\mathrm{A}$ but who invest abroad in a foreign corporation. Furthermore, Country $\mathbf{A}$ integration at the shareholder level usually does not benefit a resident shareholder who invests abroad nor non-resident shareholders investing in Country A. As one can readily discern, the resulting rules discriminate between domestic and foreign investors and investments and create tax influences that may bring powerful non-neutrality into the worldwide tax structure. Peggy Musgrave's "capital export neutrality" or "international tax neutrality" in particular will be jeopardized. $^{38}$ These unneutralities have plagued the European Common Market countries especially, in recent years. If these barriers are to be lowered without revamping the country's integration system, some extension or relief provisions must be found.

The main relief or correction for the territorial discriminations that national integration systems entail has come to be the international (double) income tax treaties. By treaty, a country can agree to extend its integration benefits to nationals of the other contracting state, such as foreign shareholders in the integrated country's (domestic) corporation. But this approach only addresses the interface between the two particular treaty countries and may not remove all integration discriminations. Moreover, treaty-making is a laborious effort, and treaties among developed countries are far more common than between developed and developing countries. So some other solution may be superior, at least for developing countries. Furthermore, selective treaty tax-reduction by granting integration relief to some foreign investors can create international competition in tax reduction; whether that is a virtue or a fault may depend on whether one takes a national or international perspective. In any event, Norr counsels that international factors, while they should not be overestimated, must be considered by a country considering integration. The impact on non-resident investors, residents considering investment abroad, or capital flight, must not be disregarded.

\section{Domestic Distinguished from International Double Taxation of Corporate Source Income}

Most countries, whatever their system of taxation of domestic corporations and shareholders, attempt to eliminate or soften international double taxation, such as is created by a tax by a source country (e.g., Germany) and the country of residence (e.g., the U.S.) on German source income of a U.S. corporation or individual. Possibly a third (U.S. shareholder) tax would apply if the U.S. person were a corporation which then distributed some of its profits to its U.S. or other individual shareholders. To cure this international

européen des capitaux: Rapport d'un groupe d'experte constituté par la Commission de la C.E.E. (1966). See also Norr at 163.

38. See Musgrave, United States Taxation of Foreign Investment Income: Issues and Arguments 104 ff. and 108 ff. (1969). 
double taxation, some countries exempt the foreign income of their nationals. Others, like the U.S., give a foreign tax credit (U.S. I.R.C. $\$ 901$ or $\$ 902$ ) for the foreign (e.g., German) source-country tax paid against the home or residence country tax also owing, to remove or reduce the double taxation. Elsewhere (and electively in the U.S.), foreign taxes may be deducted in computing the residence country's tax. International income tax treaties are often enlisted to grant relief in one form or another, often a foreign tax credit and sometimes by lowering rates on "withholding" taxes. But the treaty process has deficiencies, especially for developing countries, and particularly while the integration movement is still evolving.

When one or both of the countries, in a relationship like the one between the U.S. (residence) and Germany (source) above, decides to integrate its corporate and personal income tax domestically, intricate international problems arise. The overall problem, as concisely stated in Norr, ${ }^{39}$ lies in "correlating rules for the mitigation of international double taxation with the rules for mitigating the domestic two-tiered tax" at either the corporate or shareholder level, or both. Chapter VII is one of the best explications of this problem I have seen, rivalled only by the work of Sato, ${ }^{40}$ Bird, ${ }^{41}$ Ault, ${ }^{42}$ Cardyn $^{43}$ and McLure. ${ }^{44}$

As Norr's work shows, the problems of arranging (by tax treaty or statutory design) mutual accommodations between countries that use different corporate-shareholder tax structures turn out to be more difficult than those arising between two unintegrated country systems; integration adds complexity at the international, as well as at the national, level. The source of the difference arises from the fact that in unintegrated systems the taxation of the shareholder is unrelated, or only loosely related, to the taxation of the corporation. The corporation simply is taxed on all its profits, distributed or retained; no adjustment is made for distributions (as it would be under a dividend deduction or split-rate regime), and so it does not matter whether the shareholder-recipient of dividends is a resident or a non-resident. And, because of the independent tax status of the shareholder, he or she is taxed on dividend receipts without any, or much, adjustment for tax paid by the corporation (as there would be in a shareholder-credit integration mechanism). Since the unintegrated shareholder gets no integration adjustment, the residence of the corporation paying the dividend, or the source of its

39. Norr, at 173-174.

40. See Sato, supra n. 34. And see other good sources cited, supra n. 7 and n. 34 .

41. See Bird, supra, n. 34; "International Aspects of Integration," 28 Nat'l. Tax J. 302 (1975).

42. See Ault, "International Issues in Corporate Tax Integration," 10 Law \& Policy in International Business 461 (1978).

43. "General Report: The Multiple Burden on Dividends and Shares by Taxation on Income and Capital of Both Corporations and Shareholders," 55a Cahiers de droit fiscal international $\mathrm{I} / 39$ (1970).

44. McLure, supra n. 7 at 50-91, 223-226, and Ch. 3 ("Foreign Experience"). 
earnings, cannot matter. So, a treaty between two unintegrated systems must only interrelate the two systems to avoid international double taxation; economic double taxation is the policy of both countries and need not be corrected. In other words, it is not necessary to correlate the two systems so that the corporation tax of one country is geared to the other country's individual (shareholder) income tax, or vice-versa, and life is relatively simple. ${ }^{45}$

In contrast, if one (or both) of the two countries somehow integrates its corporate and individual income tax, the systems of the two countries must be interlocked, not only to avoid international double taxation but also sensibly to take into account integration or the distribution relief that one (or both) offers at least to its own corporation or resident shareholders. This problem remains a difficult one to solve. Norr reviews the history of some model solutions (model treaties) for the effects on inbound and outbound, direct and portfolio, investment. 6 He reports early displeasure with integration systems, and preference for unintegrated structures in the OECD in 1963, the EEC van den Temple report in 1970, and the IFA Report by Cardyn. The classical or separatist system was preferred for its "absence of discrimination" and its "technical simplicity," for purposes of international tax harmonization. An I.M.F. report in 1975 , co-authored by Sato (whose influence on the Norr book seems to have been profound), also concluded that the classical system is superior with regard to the criteria of world efficiency (capital export neutrality), the efficient allocation of capital among countries, national efficiency and inter-nation equity. ${ }^{47}$

Norr then proceeds briefly to examine the operation of unintegrated tax structures in the international arena, ${ }^{48}$ taking separately the corporate and shareholder level positions, to establish a basis for a comparison of the correlation of integrated systems and for his thesis that the latter presents very much additional complexity and non-neutrality. He then turns to an examination of internationally fitting together one or more systems integrated at the corporate or shareholder levels, ${ }^{49}$ with regard to direct investment (dividends from resident subsidiaries to non-resident parent corporations) or portfolio investment (dividends from resident corporations to non-resident portfolio investors). ${ }^{50}$ The analysis is complex and typically systematic, and only a few observations, at most, need to be made here.

The structure of the international problem varies with the form of each of the two leading internal relief mechanisms. If the form of integration taken in the residence country were a corporate level

45. See Norr at 157 .

46. See Norr at 157-160.

47. See Sato \& Bird, "International Aspects of the Taxation of Corporations and Shareholders, 22 I.M.F. Staff Papers 384, 444-45 (1975).

48. See Norr at 160-161.

49. See Norr at $162 \mathrm{ff}$. and $176 \mathrm{ff}$.

50. See Norr at 171. 
mechanism, such as a split-rate of corporate tax (mechanism), typically a rate higher on corporate income retained and lower on income distributed, an international question becomes "should that (split-rate) country extend its lower rate to distributions by a domestic corporation and made out of income from foreign sources, even if that source country exempted or preferentially taxes that income?" (Thus there arises here another version of the corporate tax preferences problem that has stymied domestic integration policy in the U.S.) Another international question would be whether the integrated country should, or must (under the non-discrimination clause of its treaties) extend the lower rate to foreign corporations who do business within its borders and who distribute their aftertax income to foreign shareholders (or even to shareholders in the integrating country).

If the integrating country uses a shareholder level mechanism, such as the imputation credit, the questions are different but parallel: Should the integrating country give (a) home or (b) foreign shareholders of a (a) home or (b) foreign corporation an imputation credit for dividends paid out of (a) home or (b) foreign source earnings, possibly taxed at a low or preferential rate (actually, if not nominally?) Norr concludes that the correlation of international with domestic double taxation forms of relief is tougher if the integration mechanism chosen is a shareholder level device and one in the form of a credit, as compared to a corporate-level device. This conclusion implies policy decisions contrary to those indicated by the earlier (domestic) chapters, which showed a strong tendency toward exactly the form of domestic (shareholder imputation credit) integration relief that causes the harder international problems. This contradiction has evolved empirically and the book describes how France, the U.K., and Germany, among others, have adopted the shareholder credit and have at least begun to solve the resulting international problems-more often by bilateral double-tax treaties than by unilateral legislation.

To put the pieces together, the reader must recall that Norr earlier reported that the shareholder credit mechanism became the preferred form for international reasons as well as domestic onesbecause it could be denied to foreign shareholders (and, one might add, tax exempt shareholders) ${ }^{51}$ much more readily than could corporate-level relief (such as a dividends deduction or a split-rate of tax) whose benefits it is hard to deny selectively among shareholders. So it becomes necessary to show, perhaps especially to the book's developing country readers, exactly what the most favored form of integration (shareholder imputation credit) ultimately has come to involve and what corrective measures may be necessary, by treaty or otherwise, if it is adopted elsewhere. This is the goal of Chapter VII and, to some lesser degree, of the entire volume. ${ }^{52}$

51. See, e.g., McLure, supra, n. 7 at 170-173, 235-238.

52. See Norr at 192. 
The international problems that stem from adopting internal integration by a shareholder credit do not consist solely of legal complexity, but also of economic or investment discrimination and allocational inefficiencies in general, and denying capital-export neutrality in particular. ${ }^{53}$ Using the French and German experiences and his usual systematic approach, Norr proceeds to examine these policy problems and some solutions. He does so in categories that take up the same features or issues or differentiations under first one level of integration (corporate) and then another (shareholder level). He thus preserves the organization and classifications of his domestic chapters (I-VI) in this international area (VII), which reveals the integrity and unity of the book and the utility of the earlier categorizations.

\section{International Influences of a Corporate Level Split-Rate Device}

Direct (vs. Portfolio) Investment. While integration at the shareholder level creates international problems mainly for non-resident portfolio investors (who are denied the shareholder credit), and creates few waves for direct investment, if distribution relief is offered at the corporate level, the international problems mainly concern $d i$ rect investment by non-resident parent corporations. By manipulating the distribution policies of their domestic subsidiaries, in ways portfolio investors as a practical matter cannot do, corporate shareholders can maximize the extent to which corporate-level distribution relief "spills-over" to the non-resident shareholders, the spillover being a function of the fraction of earnings distributed by the subsidiary.

Usually, corporate level relief is granted to domestic corporations whether they are owned by domestic shareholders or foreign shareholders. This seems to be a mutual and fair policy, but it actually creates a new discrimination in favor of a non-resident parent company. It unilaterally can control its subsidiary's dividend policy for tax (rather than for business) reasons, as happened in Germany, which used a corporate level (split-rate) relief until 1977. A German-owned German corporation that needed to use retained earnings to finance its own expansion could not afford to distribute enough earnings to maximize application of the lower rate of corporate income tax for distributed profits. In contrast, a foreign-owned German (subsidiary) company (direct investment) could be manipulated to pay out maximum earnings (which could be reinvested or loaned back by the parent-shareholder at once if needed for growth). This behavior could further be influenced if the tax treaty rate of German withholding tax on dividend were low (15\% in the German/U.S. treaty) and because the reduced statutory rate of German corporate tax on distributed earnings fell substantially below the rate on retained profits $(15 \%$ and $51 \%$, a 36 percentage point

53. See Norr at 156; Musgrave, United States Taxation of Foreign Investment Income (Issues and Arguments) Chs. VI \& VII (1969). 
differential). Norr goes on to examine this German and U.S. situation in light of the foreign tax credits allowed by the U.S. to suggest that the reduced rate of German tax merely reduced the U.S. tax credit allowed, and left a high U.S. tax in place, leaving the U.S. Treasury as the beneficiary of Germany's distribution relief. As Norr admits, however, sophisticated tax planners could counteract or defer or prevent this effect. ${ }^{54}$

In contrast, if a German subsidiary paid dividends to a German parent corporation which did not immediately redistribute them to its shareholders (possibly keeping them for reinvestment in the expanding subsidiary), a special German tax would apply. Called the Nachsteuer ("after-tax"), this levy was imposed upon the parent on a dividend it did not at once re-distribute. It thus recaptured the distribution relief enjoyed by the subsidiary under the former splitrate system by imposing this $36 \%$ tax on domestic parent corporations. It was limited to German domestic parents since foreign parents seemed out of Germany's reach, though Germany's reach over the German subsidiaries could have been used to deny distribution (rate) relief in the case of "wash" distributions by German subsidiaries to foreign parents (much as Sweden has done)-unless such action would violate the nondiscrimination clause in applicable tax treaties. $^{55}$ Increased withholding tax on dividends, instead, was used by Germany to ameliorate the problem.

\section{Portfolio Investment}

Distribution relief at the corporate level seems unlikely similarly to affect portfolio investors, who cannot control dividend policy, and who usually are not entitled to claim an indirect foreign tax credit for the corporation's payment of foreign income tax.56 In other words, unlike the case of foreign direct investors, integration at the corporate level seems unlikely to produce powerful influences on dividend payment policies from portfolio investors or to enable them to transfer revenue to their home treasuries as a consequence of interaction with the foreign tax credit, when dividends flow from resident corporations to non-resident portfolio shareholders.

As to a foreign corporation's income tax on dividends paid to resident shareholders, usually the corporate level integration relief is not available. ${ }^{57}$ With these two situations, and a third and fourth-income of resident corporations from foreign sources and income of local branches of foreign corporations-corporate level integration relief often parallels and interacts with provisions for relief from double taxation, the scope of which must be examined to judge

54. See Norr at $165-168$.

55. See Norr at 167-68.

56. See Norr at 171.

57. See Norr at 172 . There well may be a foreign tax credit or other allowance for international double tax relief. 
the neutrality and "coherence" of the international tax system, ${ }^{58}$ and must also be correlated or meshed for policy reasons. ${ }^{59}$

\section{International Influences of a Shareholder Level Credit Mechanism}

Norr sets out to show that integration, which causes difficulties in its international application, yields its most acute problems if it is installed at the shareholder, rather than the corporate, level. Shareholder level mechanisms usually give the shareholder a credit or refund of part of "his" or "her" share of the corporate income tax paid. Thus, shareholder level relief seems given by a country in its role as the shareholder's residence, not as the country of source or even as the country of incorporation. Discrimination often results, as when shareholders of domestic corporations get a credit for part of the (domestic) corporate tax while shareholders in foreign corporations do not.

A similar differentiation arises if resident shareholders in domestic corporations get a credit but non-resident shareholders (in domestic corporations) do not. And it is the common practice to deny the credit to shareholders in corporations foreign to the country of integration and to non-resident shareholders in domestic corporations: often, in fact, such deniability was part of the appeal of the shareholder level allowance. ${ }^{60}$

As to the shareholder level credit, Norr shows that denial of the shareholder-credit to foreign corporations (and to foreign shareholders) imperils capital export neutrality. (People will invest in domestic shares rather than foreign shares, or vice-versa, if everything else is equal and one but not the other carries a credit.) Not only will individual "portfolio" investors behave differently in response to a credit: corporate "direct" investors will also maneuver to maximize their after-tax (and tax-credit) return, but not always in the same way. Direct investment may be influenced in ways differing from portfolio investment.

\section{Direct Investment}

Unlike corporate level integration, which raises severe problems for direct investment, such as manipulation of dividend policy of subsidiaries to maximize their integration relief, shareholder level integration causes little trouble for direct investment, even-as Norr concludes-if the benefits of the system are limited to resident shareholders. ${ }^{61}$ This is not to say it lacks influence or mischief-the grant or denial of the shareholder credit detracts from capital-export

58. See Kingson, "The Coherence of International Taxation," 81 Colum. L. Rev. 1151 (1981).

59. See Norr at 171-175. As Norr shows, local branches may often be differentiated from local subsidiaries with respect to corporate level allowances.

60. See Norr at 176-178.

61. See Norr at 178-179. 
neutrality and will affect investment and income flows. Portfolio effects are another matter.

\section{Portfolio Investment}

If shareholder level integration relief is given along usual lines, at least the two mentioned points of discrimination will result, and the most important of the two consists of allowing resident shareholders in domestic corporations to get the credit, but disallowing it to non-resident shareholders in domestic corporations. Since the shareholder credit mechanism was adopted by France in 1965, Canada, the U.K., and Germany in 1977 adopted the credit form in order to be able to deny integration relief to foreign (sometimes particularly American) shareholders, but then selectively allowed some of it to re-enter through the back door-in treaty negotiations-in return for concessions by their treaty partners.

The various methods of treaty relief, Norr quotes The Economist as saying, amount to a "nightmare;"62 they entail, transfer payments from the French Treasury to Switzerland, or additional cash payments to U.S. shareholders who receive French dividends in order to give them the equivalent of the shareholder credit that a French shareholder would enjoy on an equal French dividend. And this attempt to eradicate discrimination between French and U.S. shareholders of French companies merely introduces a new differentialbetween U.S. persons investing in U.S. shares and those investing in French shares. (Admittedly, this new discrimination is, as Norr remarks, no more severe or invidious than that which a substantial gap in corporate income tax rates in the two countries would produce.) Norr credits Nate Gordon with pointing out that still another new discrimination arises, that between French portfolio investors in French (credit) companies or U.S. (no-credit) companies. ${ }^{63}$ Altogether, the shareholder credit integration mechanism, often chosen (despite its complicating qualities) both for sensible domestic policy reasons and because it can be denied internationally, creates important tax incentives or barriers that can distort international investment and trade and commerce and creates economic inefficiencies of major proportions.

To be sure, some tax incentives or influences may be desirable. For example, while considering integration at the shareholder level, which is usually confined to resident shareholders with respect to dividends from resident corporations, Norr notes that such integration may well serve the interests of developing countries by making investment at home more attractive than investment abroad. ${ }^{64} \mathrm{But}$, some developing countries follow the old traditional principle and do not tax their residents at home on income from foreign sources.

62. See Norr at 181.

63. See Norr at 187; Gordon, "International Fiscal Arrangements Distorted By Foreign Tax Policies: New Rules Needed," 37 J. Taxation 113 (1972).

64. See Norr at 191. 
In such countries, integration at home (with some relief from corporate income tax) seems hardly likely to offset the advantages of investing abroad, free of (shareholder) tax altogether.

\section{Integration and Source of Income}

In analyzing the international aspects of integration, Norr raises and reports experience with a dimension rarely given adequate consideration in the U.S. literature, namely the treatment given for dividends paid to shareholders of a resident corporation out of foreign source income. ${ }^{65} \mathrm{He}$ starts by noting that the country of domicile (of the shareholders) usually gives an exemption or foreign tax credit to relieve international double taxation, and then asks what will happen if the same country of domicile also gives integration relief by, for example, a shareholder credit. Further, suppose a domestic corporation pays a dividend out of foreign source income. Should such a dividend entitle the shareholders to integration relief? Should relief be conditioned on equivalent tax in the source country and be denied if the foreign income was preferentially taxed or exempted from tax?

Usually, the domiciliary country grants uniform credit relief regardless of the source of the income and the rate of tax paid on it. ${ }^{66}$ If so, Norr asks, and if the relief rests on the assumption that the corporation pays its dividend out of foreign income that has been taxed, but in fact it has been taxed at less than the full domestic rate because of relief for foreign income taxes, should any additional tax perhaps be levied on the corporation to compensate for the part of the credit attributable to the portion of the dividend that comes from tax-preferred foreign source income? France has imposed such a tax which, unfortunately, then nullified the international double tax relief. ${ }^{67}$ In contrast, Canada gives a full credit regardless of source and does not impose any additional tax, though the Royal (Carter) Commission and the White Paper recommended one. ${ }^{68}$ (That suggestion was regarded as a contradiction of incentives to invest abroad, given by Canada's foreign tax credit.)

The U.K., a country with a tradition of heavy investment abroad, (pre-1965), permitted the F.T.C. to "spill over" to shareholders, with the rate varying with the proportion of foreign source income, a rather complex solution. ${ }^{69}$ In 1973 the U.K. decided to deny the new uniform imputation (or dividend) credit for dividends paid from foreign profits. But dividends are presumed to come first from fully taxed profits, and the U.K. corporation must pay an additional tax

65. See Norr at 172-174 \& 187-191. Usually only the residence of the shareholders or the corporation is discussed; likewise his separate consideration of branches and branch accounting for taxation (at pp. $191 \mathrm{ff}$.) makes an unusual contribution. One might also say that of his highlights on withholding taxes on dividends.)

66. See Norr, Ch. VI.

67. See Norr at 188.

68. See Norr at $188-189$.

69. See Norr at $189-190$. 
(like the French precompte) called the A.C.T. (Advance Corporation Tax).$^{70}$ The U.K. corporation then may credit the A.C.T. against its corporate income tax, with other credits stacked first-so that the A.C.T. credit can be lost-and the dividend must be grossed-up (by the A.C.T.) for purposes of the shareholder income tax and credit.

So the U.K. A.C.T. often acts like a (creditable) withholding tax. ${ }^{71}$ But not always. If the corporation has no domestic source income, the A.C.T. credit will be lost and the A.C.T. will become a final additional tax. (This result naturally creates an incentive for such a firm to merge with a corporation having U.K. income.) So the sum of it is that the A.C.T. is levied to compensate the U.K. Treasury for the shareholder dividend credit to the extent the latter covers dividends from foreign sources and preferentially taxed profits. Elsewhere, a developing country might use this pattern in a deliberate policy to encourage investment at home rather than abroad.

\section{Integration and Branches of Foreign Corporations}

As to branches, Norr notes that dividend relief generally does not extend to local branches of foreign corporations, under either shareholder level relief or corporate level relief mechanisms. ${ }^{72} \mathrm{Na}-$ tions generally think that such relief is the business of the country of residence or incorporation of the foreign corporate parent which itself, as the incorporated entity, is capable of making the distribution of profits. But Norr reminds us that some countries levy two taxes on foreign branches operating within their borders-a tax on "branch profits" (calculated much as if the branch were a subsidiary corporation) and a second tax on the "distribution" of the branch (or on repatriation) if and when the foreign corporation distributes dividends "from its home office."73 France, and some developing countries modelled after France, provide examples. Yet, inconsistently, the French imputation credit does not extend to dividends from non-resident corporations even if some percentage of the underlying profits came from France and were subject to French tax on distribution. Strangely, even resident (French) shareholders in non-resident corporations having French source income do not get any benefit from ordinary French distribution relief, despite application of the French "tax on distributions." It turns out that there is a French solution for this French problem-the French tax on distributions is reduced to the extent that the foreign corporation can show that distributions were made to shareholders resident and taxable in France or to those entitled to benefit from French international tax treaties, such as its treaties with Germany and Switzerland. ${ }^{74}$

70. See Norr at $189-190$.

71. See Tiley, Revenue Law, Part IV, esp. Ch. 28 and Part VII, esp. Ch. 40. (1981).

72. Norr at 191.

73. Norr at 191.

74. Norr at 192. 


\section{CONCLUSION}

As the author(s) set out to do, Chapter VII shows that integration adds much complexity, inequitable discrimination and anti-neutral (anti-efficient) tax influences to a country's tax structure, so much so that classical or unintegrated systems may be preferred, at least in developing countries. With them especially, perhaps, domestic considerations may be paramount; nevertheless, although the international aspects of integration are unlikely to dominate the policy debate, they at least should be taken into account, this book convincingly demonstrates.

The book lacks a formal overall "Conclusion," but perhaps the "Conclusion" to Ch. VII can be taken to speak for the entire book when it reminds the reader that the EEC said unintegrated systems have marked virtues-among them simplicity and lack of discrimination. ${ }^{75}$ If any country, including the U.S. and developing countries, seriously considers integration, the Norr book, like Sato's earlier papers and McLure's articles and book, shows that its legislators must be aware of the complexities and discriminations involved and the often complex or incomplete corrective measures necessary to counterbalance the influence of integration, especially in the international arena. This may not be simply an anti-integration book, and without more economic data and analysis it could not make a complete case against integration, but the domestic and international tax factors that do form the subject of its pages make the Norr book important comparative law reading for fiscal policy makers and scholars.

75. Norr at 192.

This book does contain an Appendix at 193-197, giving an excerpt from Ault's description of the 1977 German system. Comparable material on the U.K. and French systems would have been convenient. An excellent bibliography follows, at 199-214. Unfortunately, the Norr book lacks an index (which McLure has, but lacks a separate bibliography). 